SANTOS, Roberta de Freitas;

\title{
South-South Cooperation: Brazilian experiences in South America and Africa
}

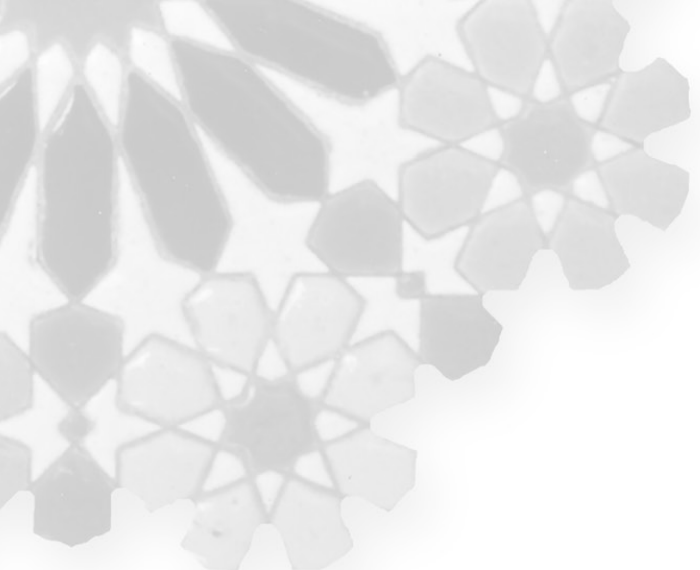

\section{Roberta de Freitas Santos}

Technical adviser, International Cooperation for Health Program, PanAmerican Health Organization/World Health Organization; associate researcher, Nucleus of Studies in Bioethics and Diplomacy, Fiocruz. Setor de Embaixadas Norte, Lote 19 70800-400 - Brasília - DF - Brazil defreitasroberta@gmail.com

\section{Mateus Rodrigues Cerqueira \\ International Relations Advisory Service/ Agência Nacional de Vigilância Sanitária. SIA, Trecho 5, Área Especial 57 71205-050 - Brasília - DF - Brazil \\ mateus.cerqueira@anvisa.gov.br}

Received for publication in July 2013. Approved for publication in January 2014

Translated by David Allan Rodgers.
CERQUEIRA, Mateus Rodrigues. SouthSouth Cooperation: Brazilian experiences in South America and Africa. História, Ciências, Saúde-Manguinhos, Rio de Janeiro, v.22, n.1, jan.-mar. 2015. Available at: http://www.scielo.br/hcsm.

\section{Abstract}

Over recent years Brazil has played an increasingly active role internationally, the result of its model of integration and its foreign policy directives. The health sector is a valuable and strategic area for Brazilian technical cooperation to achieve various objectives, including its development goals. This article describes the main directives of Brazilian foreign policy, conceptually defining and characterizing South-South Cooperation, illustrated through an analysis of two Brazilian technical cooperation initiatives in healthcare: one in South America, the other in Africa. The study concludes that, irrespective of the interests and power asymmetries existing in SouthSouth Cooperation, the objectives of this cooperation were achieved through the technical work.

Keywords: South-South Cooperation; technical cooperation in healthcare; Brazilian foreign policy; training of human resources in healthcare; drug regulation. 


\section{Brazilian foreign policy and the coalitions of "southern" countries}

\section{Brazilian foreign policy}

Over recent years Brazil has played an increasingly active role at international level, the result of its global integration and accompanying foreign policy directives. Considered a medium-level country and a regional geopolitical power, Brazil has assumed ever more functions and responsibilities congruent with the role to which it aspires or already performs internationally. Given its geographic and demographic size, its level of economic development and the wealth of its natural resources, the country claims a significant position in global politics. Lima (2005) argues that this implies a self-perception of the country of its international role, the part played by diplomacy and its elite in foreign policy, and its recognition by other States. It also requires and active role in international politics, prioritizing relations with both developing and developed countries.

As an intermediate level developing country - that is, one not included among the world powers - Brazil attaches considerable importance to multilateral institutions as a form of limiting the power of the dominant countries and preventing them from adopting unilateral measures. According to the institutionalist approach to foreign relations, participation in multiple international institutions has the potential to modify the interest of the major powers and alter the dynamic of the balance of power, as well as the security dilemma (Diniz, 2003). Strengthening multilateral mechanisms can attenuate the action of powerful countries, reducing their relative influence. Although countries with less power and resources are unable to compete equally with the major powers, these mechanisms allow them to achieve some of their own interests within the international system.

Brazil's foreign policy oscillated between two apparently conflicting paradigms: the search for autonomy and the search for international credibility. Autonomy in establishing the policy and model for international integration relates to what Keohane (1969) defines as the "system that interferes in the State." According to Lima $(2005$, p.1), those countries possessing "relatively limited resource and capacities, when compared to the major powers, but with an assertive international profile, value multilateral arenas and collective action among similar countries as a way of exerting some degree of power and influence on international outcomes." On the other hand, credibility abroad is related to recognition of the importance of globalization and to the implementation of macroeconomic reforms for the country's economic and international success. Seen from this angle, the Lula government can be said to have prioritized autonomy in foreign policy as a form of asserting the country's national interests and acting collectively with countries from the "South." Its aim, therefore, was to transform the world order and counterbalance global power by forming regional power poles (Lima, 1 jan. 2008). On the other hand, the commitment to meet the macroeconomic objectives of stability and a budget surplus, agreed among the country's centrist political coalitions, represents limits to the unconditional benefits of autonomy in foreign policy.

Historically the country has tried to act as a representative of the group of nations protecting the interests of the "South." In the coalition of Third World countries in the decade from 1960 to 1970, Brazil's diplomats believed that the country could play the role of a "bridge" between the countries of the "North" and those of the "South," acting as a 
mediator in the negotiations over the international development agenda. Indeed, the roots of South-South Cooperation can be traced to these Third World coalitions, directed towards defending the economic and political interests of the "Southern" countries vis-à-vis the hegemony of the "North." At that time, the search was for a counterpoint to north-south commercial relations, financially punitive for developing nations, by fostering trade between this group of countries.

The creation of the G- $77^{1}$ was the first strategic rapprochement between countries of the 'South,' intended to counter the economic might of the industrialized nations. This movement of non-aligned countries, which unfolded in the middle of the Cold War, was also an attempt by a group of countries, mostly "underdeveloped," to avoid becoming involved in the conflict between the two superpowers during the period, namely the USA and the USSR. The objective was to promote reform of the trade and development system, taking into account the interests of developing countries and recognizing the inequality embedded in the multilateral trade system, along with the need for a more equitable distribution of the system's benefits. In this way, the "Southern" countries successfully introduced various mechanisms, norms and principles into the trade regime, such as the Generalized System of Preferences, the principle of non-discrimination, Most Favored Nation status, special, and differentiated non-reciprocal treatment. On one hand these sought to reduce the relative benefits obtained by developed countries (recognized as hegemonic) and the adoption of unilateral measures in international trade, while simultaneously boosting the negotiating position of the countries belonging to the coalition of the "South" and defending their interests (recognizing their disadvantageous position in international trade and the principles of distributive justice).

The establishment of the G-20 group during the final preparations for the fifth World Trade Organization (WTO) Ministerial Conference, held in Cancún in 2003, was one such example of the new rapprochement between developing countries, reviving the model of earlier years. This latest form of rapprochement, classified by some authors as a coalition of "emerging markets," possesses specific characteristics insofar as it seeks to defend the group's collective farming interests and promote trade liberalization for agricultural produce in the context of multilateral negotiations, in accordance with the Doha Development Agenda.

Following this landmark event, Brazil's status among developing countries increased substantially as it became seen as a new emerging power. The country's active role specifically its proposal of alternative mechanisms for integrating developing countries in the international system, advocating on the basis of their common interests and priorities and increasing their negotiating power vis-à-vis the countries of the "North" - provided it with a degree of leadership in relation to other countries of the "South." In this way, a form of collaboration clearly exists among this group at the multilateral negotiating tables on issues like trade, the environment, health and so on.

\section{Characteristics of Brazilian foreign policy}

Given the contextualization provided above, we can establish the general lines and main characteristics of Brazilian foreign policy. Firstly, in relation to its search for autonomy at international level, Brazil vigorously defends the principles of multilateralism, the selfdetermination of peoples, non-intervention in the domestic affairs of other States, and 
respect for international law. Other Brazilian foreign policy principles include peaceful conflict resolution, non-indifference, the emphasis on economic roots related to questions of international security, democratic values, solidarity and the strengthening of multilateral mechanisms and institutions.

The constitutional principles concerning international relations are the same as those informing Brazil's foreign policy and the international cooperation provided by the country, including the "prevalence of human rights, the self-determination of peoples, equalities between States, and cooperation between peoples towards human progress" (Brasil, 1988).

One of Brazilian diplomacy's characteristic is the institutionalization of foreign policy through Itamaraty (Ministry of Foreign Affairs), a diplomatic corps respected both domestically and internationally, with autonomous decision-making, institutional memory, professionally-trained diplomatic staff, and committed to acting as an instrument in the country's development project.

Additionally, active presidential diplomacy is another clear feature of Brazilian foreign policy to be factored into the implantation of national policies. Since Fernando Henrique Cardoso's government, and increasingly under the Lula government, Brazilian foreign policy has very notably involved the President of the Republic's attendance of bilateral and multilateral missions, meetings and fora, his or her direct involvement in trade negotiations, an increase in the country's signing of international agreements and treaties, as well as cooperation agreements made with a variety partners (Cason, Power, 2009). President Lula's inauguration speeches for his first and second mandates provide evidence of this pro-active presidential diplomacy, confirming the strong interest in foreign policy issues and indicating some of the government's directives and priorities in relation to the question of international integration: "We are close to Africa, one of the cradles of Brazilian civilization. We have made the South American neighborhood the center of our foreign policy. Brazil links its economic, political and social destiny with the continent, Mercosur and the South American Community of Nations" (Lula da Silva, 1 jan. 2007).

The representatives of the Republic now play a leading role in communicating the changes in the national development model, which has resulted in new global partnerships signed by Brazil as a form of rethinking the country's position and role within the international system. During this period there was a change in the national leadership responsible for setting foreign policy guidelines and, consequently, a dilution of Itamaraty's monopoly in this field.

It should be emphasized that as well as working to achieve international political objectives and the interests of its national elites, Brazilian foreign policy also has a social purpose: in other words, it is used as an instrument for the country's development and as a means for solving its social issues. In this sense, foreign policy and the international cooperation provided by Brazil have a strongly "developmentalist" flavor. In terms of Brazilian cooperation in health, a topic explored later in this article, the inclusion of international cooperation as a key aspect of the Mais Saúde Program (2008-2012) and the National Health Plan (2012-2015) is explained as a strategy for strengthening Brazil's Single Health System (Sistema Único de Saúde - SUS) through international cooperation initiatives: exchanging experiences, the universalization of the health systems and services of South American nations, the Community of PortugueseSpeaking Countries (CPLP), Haiti, and so on. 
Brazil's development of closer links with countries of the "South" reveals an innovative policy of opening up distinct channels of cooperation in the global political environment. The geographic regions prioritized by Brazilian foreign policy are South America, Latin America, the Caribbean and Africa, especially countries belonging to the African Countries of Portuguese Official Language (PALOP). Reflecting these geographic priorities, the case studies presented in the second part of this article focus on the analysis of two Brazilian experiences of South-South Cooperation, one in South America (the CIRHUS Program) and the other in Mozambique, Africa (Project for Strengthening the Mozambican Drug Regulatory Authority). In addition, Mercosur ${ }^{2}$ remains a key arena for the country, alongside the emergence of new initiatives for integrating countries from the South American region, emphasizing this geographic area as a priority for Brazilian foreign policy.

The creation of the Union of South American Nations (USAN), a South American political community, resulted from the emphasis given to the region by Brazil's foreign policy. ${ }^{3}$ In December 2008, the South American Health Council was created under the auspices of USAN. Formed by the Health Ministers from the community's 12 member countries, its objective is to consolidate the integration of healthcare across South America, helping achieve the aim of health and development for all. The Health Council has established five key areas for health: (1) an epidemiological shield; (2) the development of universal health systems; (3) universal access to medications; (4) promotion of health and action on social determinants; (5) development and management of human resources.

The other countries in the Latin American and Caribbean regions are also priorities, forming part of the global neighborhood and belonging to the zones of influence of Brazil and the USA. The African continent also shares common roots with Brazil due to the processes involved in European colonization, the linguistic connections shared with Portuguese-speaking countries, cultural proximities - "Brazilian Africanism," as Saraiva calls it (2001, p.32) - and the elements that have gone into shaping Brazil's identity and its emergence as a sovereign and independent nation. In this respect, the country has recently revived commercial, diplomatic and strategic relations with Africa in diverse areas, including economic, social, environmental and political development and cooperation.

One key challenge for foreign policy is to reduce regional asymmetries and forge closer ties between the region's countries. These aims in mind, Brazil has been endeavoring to work on border issues (trade, health, migratory flows, infrastructure), seeking to promote better integration with neighboring countries. In this way, Brazilian diplomacy has shown its determination to consolidate the nation's position as a regional leader, interconnecting aspects like security, the defense of democracy, integration processes and prospects for national development (Lima, 2005, p.48). The increased interactions (commercial, economic, social and cultural) between South American countries strengthens the continent and its relative position as a block vis-à-vis other country coalitions.

International security issues are also of keen interest to Brazil as a nation. The country has led the United Nations peace-keeping process in Haiti since 2004 - United Nations Stabilization Mission in Haiti (MINUSTAH) - reflecting its intentions in the military field. Brazil's cooperation with Haiti, especially in the health area, was scaled up following the natural disasters that hit the country in 2010. 
Also in this policy area, Brazil campaigns internationally for reform of the United Nations Security Council to make it more democratic by expanding the number of permanent members, including a seat for itself. A debate indeed exists on these being Brazil's ultimate interests, which would explain its constant search for a prominent international role. At the same time that the USAN Health Council was created, its Defense Council was also instituted, showing the importance of the issue of security for the countries belonging to this community.

In terms of innovative cooperation initiatives with Southern countries, Brazil formed the IBSA coalition (India, Brazil and South Africa Dialogue Forum). This trilateral forum is based on a shared commitment to democratic institutions and values, and support for multilateral agencies in solving economic, political and security problems. IBSA also develops joint initiatives linked to the fight against poverty and to development policies. It responds to economic, international security and social questions, including via a health subgroup that promotes international cooperation initiatives in areas such as epidemiological and sanitary surveillance, public health laboratories, combatting counterfeit medicines, Millennium Development Goals, and campaigns against smoking and influenza A.

Brazil also belongs to the group of countries known as BRICS, formed by Brazil, Russia, India, China and South Africa. According to former Foreign Minister Celso Amorim, this group of emerging countries, possessing a considerable capacity to influence the global economy, aims to consolidate itself politically as a block capable of balancing and democratizing the international order in the twenty-first century (Amorim, 8 jun. 2008, p.8).

Another South-South Cooperation initiative worth mentioning is the Community of Portuguese-Speaking Countries (CPLP), which possesses the status of an international body, formed by eight countries. ${ }^{4}$ Its activities in the health field is based on the CPLP Strategic Plan in Health Cooperation (Pecs/CPLP), ${ }^{5}$ which looks to achieve synergies in the health area, reinforcing local healthcare systems with the aim of influencing social determinants of health as a means to achieving the Millennium Development Goals. The Plan prioritizes the following areas: reducing child mortality, improving access to reproductive health and reducing in maternal mortality, and combatting HIV, malaria, tuberculosis and other endemic infectious diseases. In general terms the countries recognize health as a right of everyone and an obligation of the State, emphasizing the importance of universal access to health services with an emphasis on primary care.

Today technical cooperation can be perceived as a Brazilian foreign policy instrument, designed to attain the country's objectives in relation to development and international integration. Brazil plays an active role in fostering closer relations with nations possessing different levels of development. The technical cooperation initiatives represent a concrete mechanism for cultivating these relations and exchanging information, experiences and technologies between countries of the South.

\section{South-South Cooperation}

\section{A brief attempt at conceptualization}

South-South Cooperation has emerged as an initiative complementing Official Development Assistance (ODA) and compensating for the reduced supply of cooperation 
from habitual donors, who, owing to global pressures, economic changes and political phenomena, abruptly altered their aid priorities, in relation to geographic areas and the issues addressed (Fiocruz, 2008).

According to Almeida et al.:

So-called South-South Cooperation (or technical cooperation between developing countries), a foreign policy instrument for promoting the international development of 'non-aligned countries,' created at the end of the 1970s, is becoming increasingly important. The political and economic setting in the 1990s, at both national and international level, represents a significant turning point for South-South Cooperation and more particularly for Brazilian foreign policy (Almeida et al., mar. 2010, p.26).

South-South Cooperation, a fairly complex concept according to the South-South Cooperation Special Unit of the United Nations Development Program (UNDP), is essentially a process through which two or more countries work together to develop their capacities through exchanges of knowledge, abilities, resources and technologies (UNDP, 2004). It primarily involves countries sharing their specialized capacities and successful experiences in a more horizontal, solidary and integral relationship than the classic "North-South" cooperation with its one-way tendencies.

UNDP's Special Unit claims that the concept developed in accordance with its components: Economic Cooperation between Developing Countries and Technical Cooperation between Developing Countries (TCDC). Seen in these terms, TCDC has the more immediate aim of "mutually potentializing the capacities of determined sectors (for example: education, health, infrastructure and tourism) with some impact on the economic and social development of the countries involved" (SEGIB, 2008, p.16).

At national level, the Brazilian Cooperation Agency (Agência Brasileira de Cooperação $\mathrm{ABC}$ ) internalized this concept as follows:

Horizontal cooperation refers to the technical cooperation implemented by Brazil with other developing countries. By sharing experiences and the knowledge available across a wide spectrum of Brazilian institutions with institutions from other countries interested in cooperation with Brazil, their relations can be promoted and deepened in various dimensions within the framework of a foreign policy based on solidarity in the area of Cooperation towards Development (Brasil, s.d.c).

It should be emphasized that the concept of South-South Cooperation is not limited to the cooperation established between developing countries, or to the geographic location of the cooperating countries. According to the Ibero-American General Secretariat, ${ }^{6}$ SouthSouth Cooperation is defined by the following basic principles:

Horizontality: South-South Cooperation requires that countries collaborate with each other as equal partners. This means that, irrespective of their different levels of development, collaboration is established voluntarily without any party linking its participation to the setting of conditions.

Consensus: The execution of an action of South-South Cooperation must be submitted to consensus by those responsible from each country, within a common negotiation framework, through mixed commissions or their equivalent. 
Equity: South-South Cooperation should be realized so that its benefits (very often consisting of mutually potentializing capacities critical to development) are distributed equitably among all the participants. This same criterion should also be applied in the distribution of costs, which should be assumed in a shared form proportional to the real possibilities of each party (SEGIB, 2008, p.16).

South-South Cooperation, as an important element of international cooperation towards development, provides viable opportunities for developing countries and countries with transition economies to individually and collectively achieve economic growth and sustainable development (United Nations, 2007).

\section{Main historical landmarks of South-South Cooperation}

The agenda for cooperation between developing countries is based on the demands for policies stimulating economic and social equity and progress after the Second World War. This agenda was driven in the first half of the 1960s by a series of events and meetings that enabled the concept of South-South Cooperation to become more clearly defined (SEGIB, 2008), including the United Nations Conference on Trade and Development and the Group of 77 (G-77) in 1964, which began to discuss cooperation:

From the mid-1960s, the decolonization movements, dependency theory and movement of 'non-aligned countries from the Southern hemisphere' combined to produce hard-hitting critiques of the modernization paradigm, which further stimulated the reflection on international cooperation towards development worldwide (Jolly cited in Almeida et al., 2010, p.26).

From the 1970s debate began to focus on the accumulation of positive experiences among developing countries that could be transferred to other countries facing similar problems. A series of multilateral discussions set out the principles, characteristics and modalities that led to the construction of a concept of TCDC as an alternative to North-South cooperation (SEGIB, 2008).

In 1974 the Special Unit for TCDC was created by the United Nations within the framework of UNDP, which launched studies in support of this form of cooperation. In 1978, draft guidelines proposed at the United Nations Conference on TCDC and the latter's recommendations were taken up by the Buenos Aires Action Plan (BAPA).

The 1970s witnessed the first significant reorientation of international cooperation with the introduction of the Basic Human Needs (BHN) approach, which incorporated greater concerns with the human and social aspects of development. A set of initiatives paved the way for new opportunities for building alliances between countries of the South (Almeida et al., 2010, p.26).

In the 1980s, with the exception of the United Nations High-Level Conference on TCDC held in Caracas, in 1981, where an action program was established to support this form of cooperation, signaling "an important advance in terms of the successful operation of this modality of economic cooperation between developing countries" (Amador, 2001, p.4), no important cooperation actions took place between developing countries, or an other event of special relevance: 
In the 1980s, in the wake of the second oil shock (1979) and the subsequent economic crisis, the neoliberal principles imposed by the loan conditions linked to Structural Adjustment Programs (SAP) were at the core of the formulations at economic and political level and in international cooperation. In this context, TCDC suffered setbacks and the political and administrative shortcomings diagnosed in developing countries were tackled through programs designed to strengthen government institutions ('institutional development') with the training of national personnel to perform 'essential functions' (Almeida et al., 2010, p.27).

During the 1990s, the economic growth experienced by a number of developing countries helped strengthen some of their internal capacities (Naslausky, jan-abr. 2002). The coincidence of this factor with the increasing tendency to reduce ODA (Amador, 2001) has provided these countries with better options, allowing them to offer cooperation and transform South-South Cooperation into an important tool for further development:

As a result, international technical cooperation transformed into an auxiliary instrument for promoting national development and an important mechanism for achieving closer relations between countries. To contribute to the process of socioeconomic development, the ITC aims to transfer knowledge between an international body and a country, or between countries, on non-commercial terms, with the aim of attaining pre-defined objectives agreed between the parties on a specific issue (Brasil, s.d.b).

Through new TCDC guidelines ${ }^{7}$ and the Doha Plan, ${ }^{8}$ South-South Cooperation ${ }^{9}$ is now expanding constantly in all its different modalities: "What happened internationally in terms of an increase in commercial and financial flows between countries of the South reflects a significant level of development that these countries succeeded in achieving in relation to some of their technical and financial capacities, as well as the possibilities of transfer to other countries" (SEGIB, 2008, p.15).

With the aim of maximizing the solutions available for helping to solve the familiar and emerging challenges of the "South," the United Nations Secretary General, in his report to the UN General Assembly 60th Session (A/62/295), among other things, urged the international community, including the United Nations System, to help amplify the impact of South-South Cooperation by: (a) using approaches based on South-South Cooperation to achieve the Millennium Development Goals; (b) increasing multilateral support for SouthSouth initiatives as a way of responding to common development challenges; (c) promoting inclusive partnerships for South-South Cooperation, including triangular and public-private partnerships; (d) improving the coherence of the United Nation's support for cooperation; and (e) stimulating innovative funding for South-South and triangular cooperation (United Nations, 2007).

In this context, drawing from a long history of cooperation and assistance between developing countries, many nations have become important partners towards development (United Nations, 2012). Over recent years, various countries from the "South" have built up significant technical and financial capacities, transferring some of these resources to other countries from the "South" as part of a wide-ranging approach of South-South Cooperation towards the management of global programs. 


\section{Brazilian Technical Cooperation}

As one of the actors closely involved in this process in Brazil, the Brazilian Cooperation Agency $(\mathrm{ABC})$ - which forms part of the formal structure of the Ministry of Foreign Affairs is the body responsible for coordinating Brazil's technical cooperation. The Agency has a director with a mandate and possesses its own financial resources to promote technical cooperation initiatives in the countries of interest:

International technical cooperation comprises an important development tool, helping a country to promote structural changes, including State actions, through institutional strengthening initiatives. The programs implemented within its framework allow the transfer or sharing of knowledge, experiences and good practices through the development of human and institutional capacities with the aim of achieving a long-lasting qualitative leap (Brasil, s.d.a).

ABC coordinates initiatives for horizontal collaboration received from abroad. The cooperation obtained from other countries encompasses bilateral and multilateral technical cooperation, seeking to internalize the technical knowledge provided by international bodies (multilateral cooperation) and more developed countries (bilateral cooperation) with the aim of accelerating the process of national development.

The initiatives submitted for the Agency's approval are evaluated in terms of the extent of their impact on the communities involved. This procedure involves an enhancement of the mechanisms for negotiating, assessing and managing projects with the objective of adapting them to national priorities. One example is the project for institutional strengthening of the Mozambican Drug Regulatory Authority, executed by Brazil's National Health Surveillance Agency (Agência Nacional de Vigilância Sanitária - ANVISA) and the Mozambican Ministry of Health (MISAU). This project will be analyzed more closely later since it provides a good illustration of a technical cooperation project receiving financial and technical support from ABC.

\section{Brazil's South-South Cooperation in health}

Among the principles orienting the Brazilian Democratic Constitutional State, set out in the 'Citizen Constitution' promulgated in 1988, we find the basis for South-South Cooperation in health: at domestic level, Article 3, Item I, of the Federal Constitution (FC), aims to achieve the ideal of a free, just and solidary society. At international level, Article 4, Items II, V, VI and IX of the FC, advocates policies that emphasize the prevalence of Human Rights, equality between States and the defense of peace - in sum, cooperation between the world's peoples towards global development: "The 1988 Brazilian Constitution opted for the Cooperative Constitutional State and requires a Cooperative Constitutional Law that makes this option viable" (Maliska, maio-jun. 2007, p.630).

In this respect, the right to health, recognized in Article 6 of the FC as a basic human right, represents a singular landmark in the redefinition of the priorities of the State's policy in the area of public health. This recognition imposes on Brazil the duty to develop healthcare initiatives and services in accordance with the content of Chapter II, Section II, articles 196 to 200 of the Constitution, and in other infra-constitutional norms: 
Health has come to be recognized as one of the most important aspects of human life, a basic need of human beings and thus ultimately a fundamental right of the human person. Recognized concomitantly are the duties and responsibilities of governments and of all those entities able to influence health, thereby implying, among other things, the constant search for new knowledge, the ceaseless improvement of the technical infrastructure, permanent educational activities, the allocation of public funds, and the creation of special services, recognized as indispensable, towards healthcare (Dallari, 2003, p.77).

In an interview published in Cadernos da Escola de Direito e Relações Internacionais da Unibrasil (Maliska, jan.-dez. 2007), Häberle explains, making references to his own work, the elements contributing to the development of the Cooperative State: these include an opening to international relations, the constitution's potential to develop these relations, and the State's solidarity in providing assistance, that is, its willingness to cooperate beyond national boundaries, support for development, environmental protection and so on.

For Brazil's Ministry of Health, therefore, the national foreign policy agenda put into effect by international cooperation in health is based on the principle of solidarity as part of a concern with the health of a "global community."

The cooperation between Brazil and other developing countries, denominated SouthSouth Cooperation, in the area of health, is based on a number of guiding principles in the management of Brazilian public health: health as a universal right and the duty of the State, equality of care, integrality of the medical service, universal coverage of public health services, social participation and oversight, free access to the services provided, and so on. In addition the principles regulating Brazilian cooperation in health should also be mentioned: cooperation between peoples towards human progress, respect for national sovereignty, economic independence, equal rights and non-intervention in the domestic affairs of other nations, horizontality in cooperation actions, respect for cultural diversity and the sustainability of actions (OPAS/OMS, s.d.).

In accordance with the directives of Brazilian foreign policy, International Technical Cooperation for Health has become an important instrument, helping to

Strengthen Brazil's presence in the international setting (meeting the challenge posed by President Lula during the ABRASCO conference), developing closer relations with the Ministry of Foreign Affairs, expanding our presence in sectoral agencies and United Nations health programs - like WHO, PAHO, UNITAID, FIAM and many others, as well as cooperating towards the development of the health systems of South American countries - especially with Mercosur, Portuguese-speaking African countries and CPLP (Temporão, 2007, p.6).

Following the approval of the South American Health Council, USAN became another priority for the Ministry of Health and the Brazilian government in the process of regional integration (Brasil, 2009).

International Cooperation in Health is one of the keystones of Brazil's National Health Policy (2008-2011),

contributing to the development of sustainable health systems with cooperation initiatives in conjunction with structuring institutions, which include: public health 
schools, technical health schools, public health institutes and centers producing basic materials (immunobiologicals and medications). The promotion of support and promotional activities in the areas of documentation, information, technical and scientific communication centers and collaborative networks are also incorporated in this initiative. Its aim is to develop an area with a huge potential to contribute to the strategies of Brazilian foreign policy, directed towards cooperation, at the same strengthening regional blocks and relations of solidarity with sister nations (Brasil, 2008, p.81).

It is important to emphasize that this approach is maintained in the current National Health Plan (PNS 2012-2015):

Based on the directives of Brazilian Foreign Policy, the international health initiatives undertaken by the Ministry of Health look to promote, coordinate and guide the government's dialogue with other countries and multilateral bodies, as well as in international forums of interest to the sector. It also encourages the adoption of regional and sub-regional integration mechanisms, as well as developing collaborative actions with experts and multilateral and bilateral international missions, thereby fulfilling the directives of national health policy (Brasil, 2011, p.54).

More specifically, Directive 14 of the Plan stipulates the "international promotion of Brazilian interests in the health field, as well as sharing SUS's experiences and knowledge with other countries, in line with Brazilian Foreign Policy directives" (Brasil, 2011, p.98).

Brazil possesses diverse initiatives in the health sector in various countries and can be said to have accumulated some experience in the area. The number of International Actions in Health increased by around 500\% during the period from 2003 to 2008. If we take into account geographic distribution, there is a clear prioritization of Brazil's relations with South America and Africa. The main themes covered by Brazilian cooperation in health are headed by HIV/AIDS, followed by milk banks, malaria, health monitoring, teaching and investigation, and health systems (Queiroz, 2008). All of this has helped consolidate the field of international health, involving the actions of not only diplomats and representatives from the Ministry of Foreign Affairs, but also technical staff, experts and managers linked to the Ministry of Health and its units, as well as the other institutions working on healthrelated issues.

In this vein, the Brazilian government has an interest in disseminating the proposal of the national health system with the aim of strengthening the institution in a double sense: through the exchange of knowledge and technologies accumulated by other countries, and by emphasizing international recognition as a health policy model. This approach is consistent with the general directives of Brazilian foreign policy, related to establishing alliances with other countries in the defense of common interests. In this case the aim is to strengthen a proposal for the health sector informed by the doctrine of building healthcare systems with universal, equitable and integral coverage. The cooperation initiatives with the institutions composing the regional health system of the Americas and African countries play an important role in the development of universal healthcare systems, boosting the epidemiological surveillance of transmissible and non-transmissible diseases, the training of human resources, medication access policies, the development of immunobiologicals, and so on. 
One concept proposed by researchers from the Fundação Oswaldo Cruz (Fiocruz) is "structuring cooperation for health," which is related to the concept of "capacity development," to use the term defined by UNDP. This concept is based on the view that technical cooperation for health should work to integrate the development of human resources for health with organizational and institutional development as a means to achieving integral and structuring action in the field. In addition "structuring cooperation for health" aims to exploit the endogenous capacities and resources of the participant countries (Almeida et al., 2010, p.29).

The development of human resources concerns training activities in areas such as investigation, teaching, services, regulation, production and so on (Almeida et al., 2010). However, this capacity-building should not be focused solely on official technical staff, disconnected from the organizational structure to which these individuals belong. On the contrary, 'structuring cooperation' must be concerned with the structuring and strengthening of health bodies in the countries, including Ministries of Health, Public Health Schools, National Health Institutes, Technical and Polytechnic Colleges, National Production Institutes, National Laboratories and Drug Regulatory Authorities (Almeida et al., 2010). These organizations need to possess their own capacity to work in a determined health field in their territory. Similarly their structuring cannot be dissociated from the macro-structures of this sector within the country, such as the national health systems, for example.

'Structuring cooperation' therefore aims to increase the capacity of the country's institutions to work globally in the health sector. National capacities for intersectoral action need to be improved as part of the development of more robust health systems. The national appropriation of these different levels of healthcare (micro, meso and macro) is fundamental to the effective and autonomous structuring of the health sectors of the different countries involved.

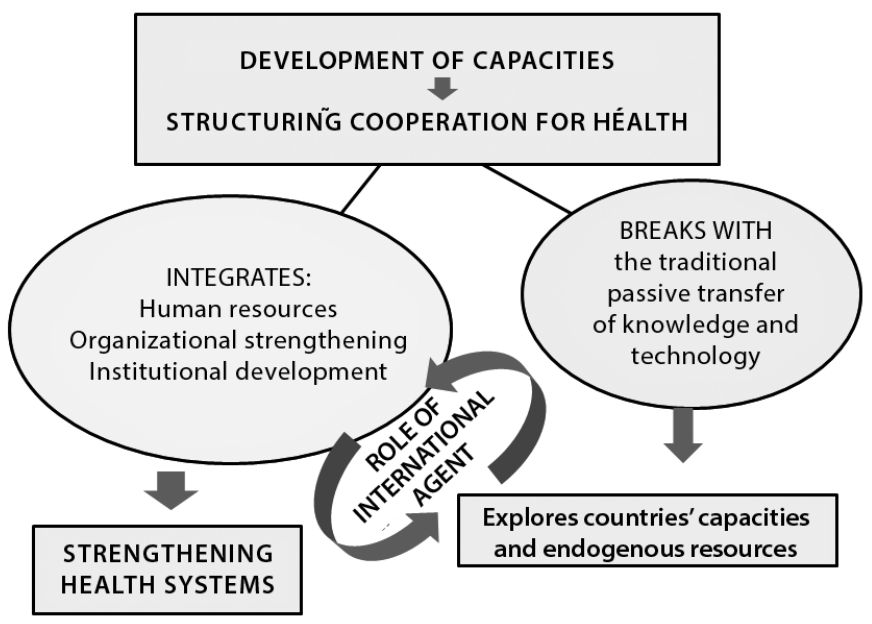

Figure 1: The concept of "structuring cooperation for health," conceptual and operational innovations (Almeida et al., 2010, p.29). 


\section{PAHO/WHO triangulation}

As a public health body, the Pan-American Health Organization (PAHO/WHO) is dedicated to improving the health of the region's countries. Processes may vary according to the different national contexts concerned, but irrespective of these variations, the organization aims to help improve the quality of life of the region's population.

The South-South Cooperation triangulated by PAHO/WHO dates back to the start of the twentieth century, since when it has presented numerous objectives, initiatives and achievements realized through the combination of efforts and investments.

Here we can highlight Brazil's commitment to execute cooperation initiatives with the triangulated participation of the United Nations along with PAHO/WHO:

We shall face the challenges of the present like terrorism and organized crime by investing in international cooperation, based on the principles of multilateralism and International Law. We shall support the efforts to make the UN and its agencies agile and effective instruments in promoting social and economic development to fight poverty, inequalities and all forms of discrimination, defending human rights and preserving the natural environment (Lula da Silva, 1 jan. 2003).

For the Ministry of Health, Brazilian technical cooperation for health is amplified by a strong Brazilian presence at the United Nations:

Strengthening Brazil's presence in the international setting (meeting the challenge set by President Lula during the ABRASCO congress) through the development of closer relations with the Ministry of Foreign Affairs, expanding our presence in the sector-based organization and in United Nations health programs - like WHO, PAHO, UNITAID, FIAM and many others - as well as cooperating with the development of health systems in the countries of South America - especially with Mercosur - and with Portuguese-speaking countries in Africa and CPLP (Temporão, 2007, p.4).

The technical cooperation strategy of PAHO/WHO with Brazil (CCS 2008-2012) (OPAS/ OMS, 2007) is oriented towards defining Terms of Cooperation, based on the principles of establishing priorities, in accordance with the country's regional and global commitments, and also on management supported by results, which requires collective planning and evaluation.

Along these lines, Brazil has been developing diverse cooperation initiatives in the health sector, various of them implemented through the PAHO/WHO triangulation, in joint initiatives with Brazilian institutions that form part of the wider cooperation process. PAHO/ WHO supported a variety of cooperation initiatives involving the Brazilian government in the health sector through the International Cooperation for Health Program (TC41), agreed by the PAHO/WHO, the Brazilian Ministry of Health (MH) and the Fiocruz. The aim of this program was to promote the development of knowledge and the exchange of experiences and technologies in response to some of the core health problems faced by Brazil and other member countries of PAHO/WHO, with priority given to South America and Portuguesespeaking Africa, highlighting solidary development as a means to achieving the Millennium Development Goals.

Also with the objective of pursuing and strengthening cooperation, in order to improve the efficacy of their activities and attain their shared aims in the health field, a Memorandum of 
Understanding (MoU) was agreed between WHO and CPLP, precisely in order to implement cooperation initiatives between nations from the Community of Portuguese-Speaking Countries with the triangulation of WHO. Through this agreement the parties commit to closer technical cooperation in pre-defined areas and to develop synergies around common objectives constructed on the basis of comparative strengths and advantages.

MoU's intention is to establish the general terms and conditions for cooperation between the parties. The priority areas in which cooperation for health initiatives are established are:

- education and development of health workforce;

- information and communication in health;

- investigation in health;

- development of medical technology;

- epidemiological surveillance and health control;

- emergencies and natural disasters; and

- health promotion and protection.

This triangulation has proven essential to the development of healthcare in these countries, since it enables the optimization of resources, the exchange of experiences, knowledge and technologies, as well as constructing an environment for dialogue that allows a better understanding of the situations experienced by other countries and a form of action based on needs, solidarity and respect.

In the current context, PAHO/WHO performs the important function of strengthening sub-regional cooperation with Brazil's active involvement, making use of its national capacities while simultaneously responding to its own domestic needs and demands. In this way, it supports the incorporation and implementation of a growing agenda of triangular SouthSouth initiatives, as defined in the country's international cooperation policies.

\section{Proposal}

In an attempt to summarize the main characteristics of South-South Cooperation, as well as propose an analytic model for the case studies of technical cooperation discussed below, we have developed a matrix with the main features of South-South Cooperation, including concepts and a brief interpretation. This matrix was compiled by the authors themselves, based on the surveyed literature and various reference documents. Methodologically this data will serve to assess the Brazilian South-South Cooperation initiatives selected for this study.

Box 1: Matrix of South-South Cooperation Directives

\begin{tabular}{|l|l|}
\hline \multicolumn{2}{|c|}{ Main Characteristic Features } \\
\hline Horizontality & $\begin{array}{l}\text { - Relations between developing countries, established voluntarily, without the } \\
\text { imposition of conditions and/or concessions (economic, political etc.) }\end{array}$ \\
\hline Consensus & $\begin{array}{l}\text { - Subject to negotiations in equal conditions, in accordance with each country's } \\
\text { priorities } \\
\text { - Taking into account various principles and values, such as: sovereignty, non- } \\
\text { interventionism, self-determination of peoples, respect for cultural differences, } \\
\text { autonomy }\end{array}$ \\
\hline
\end{tabular}


Box 1 (cont.): Matrix of South-South Cooperation Directives

\begin{tabular}{|c|c|}
\hline \multicolumn{2}{|r|}{ Main Characteristic Features } \\
\hline Equity & $\begin{array}{l}\text { - Recognition of the potentialities of the countries involved } \\
\text { - Shared distribution of the costs, proportional to the possibilities of each party } \\
\text { - Mutual benefits and responsibilities }\end{array}$ \\
\hline Solidarity & $\begin{array}{l}\text { - Strengthening of cultural ties and friendship } \\
\text { - Independent of economic and financial benefits }\end{array}$ \\
\hline Innovation & $\begin{array}{l}\text { - Use of innovative approaches and proposals for effectiveness } \\
\text { - Availability of secondary financial resources }\end{array}$ \\
\hline Sustainability & $\begin{array}{l}\text { - Proposal of mechanisms for the maintenance and duration of the initiative } \\
\text { - Long-term autonomy of the project }\end{array}$ \\
\hline Strategy & $\begin{array}{l}\text { - Defined in accordance with the interests and foreign policy directives of each } \\
\text { country } \\
\text { - Defined in accordance with national priorities and needs }\end{array}$ \\
\hline Transparency & $\begin{array}{l}\text { - Actions publicly accountable } \\
\text { - Participatory process in accordance with collective interests } \\
\text { - Clear and accessible information }\end{array}$ \\
\hline Commitment & - Political, institutional and technical commitment \\
\hline Leadership of the "South" & $\begin{array}{l}\text { - Originating from the active leadership of the countries involved, focusing on } \\
\text { their priorities } \\
\text { - Absence of donors or initiatives led by outside actors, owned by the national } \\
\text { institutions } \\
\text { - Appropriation of the initiatives by member countries and implementation of } \\
\text { their own development strategies }\end{array}$ \\
\hline \multirow[t]{2}{*}{$\begin{array}{l}\text { Exchange of Integration } \\
\text { Experiences }\end{array}$} & $\begin{array}{l}\text { - Joint construction of knowledge } \\
\text { - Incomplete knowledge; produced by the parties involved }\end{array}$ \\
\hline & $\begin{array}{l}\text { - Wide range of actors involved } \\
\text { - Collective definition of priorities } \\
\text { - Respect for the wider context of the cooperating countries }\end{array}$ \\
\hline Structuring & $\begin{array}{l}\text { - Development of human resources } \\
\text { - Organizational development } \\
\text { - Institutional strengthening }\end{array}$ \\
\hline Effectiveness & $\begin{array}{l}\text { - Fulfillment of the objectives initially proposed by the initiative } \\
\text { - Concern with the results, reflecting the existence of limited resources } \\
\text { - Rationalization of available resources in order to make the initiatives cost- } \\
\text { effective } \\
\text { - Consideration of the capacities initially installed as a starting point for generating } \\
\text { improvements } \\
\text { - Search to increase the alignment and harmonization of development assistance } \\
\text { and elimination of duplication of efforts }\end{array}$ \\
\hline
\end{tabular}

Source: Table compiled by the authors based on information taken from SEGIB (2008), UNDP (19 dez. 2004), Almeida et al. (mar. 2010), UNDP (1997) and OECD (28 fev.-2 mar. 2005).

\section{Case studies}

\section{The International Specialization Course in Human Resource Management in Health}

The initiative triangulated by $\mathrm{PAHO} / \mathrm{WHO}$ through the International Cooperation for Health Program (TC41), in the context of South American (including Andean) countries, is based on the Brazilian experience of training human resource managers: 
The Brazilian experience with the CADRHU project, implemented in close collaboration between PAHO/Brazil, the Ministry of Health and Brazilian Universities, accumulated knowledge and technology that should be shared with other countries, helping to consolidate advances that have already been achieved in this strategic area as part of the process of implanting the Brazilian Single Health System (Victoria, 2010, p.6).

This initiative was undertaken as the first step towards establishing a supply of specialization of human resources for health policy managers in each country, supporting the development of national capacities for leading and directing policies linked to human resources for health, as well as supporting the formulation of action plans for the development of human resources for health as part of a "Decade of Human Resources for Health in the Americas." 10

The reasons for this demand include: lack of diagnosis of human resources; insufficient management capacity and operational problems related to shortfalls in human resource training; the distances separating training institutes from the health services, hindering the search for solutions to problems in the human resource area, as well as the lack of preparedness of universities to deal with issues related to management of work in the health sector.

Applying the "Matrix of South-South Cooperation Directives" allows us to determine the project's main characteristics, objectives, phases and associations.

The box clearly shows that the characteristics converge, revealing the presence of common elements in more than one directive, which strengthens, rather than lessens, the importance of the overlap.

Box 2: Matrix of South-South Cooperation Directives applied to the CIRHUS case

\begin{tabular}{|l|l|}
\hline Characteristic & Development \\
\hline Horizontality & $\begin{array}{l}\text { - Initiative that combines the efforts of countries from the South (Brazil and } \\
\text { countries from the Andean and Southern Cone sub-regions) to achieve mutual } \\
\text { results without the imposition of conditions or concessions. } \\
\text { - Triangulation of an International Body of the United Nations, respecting the } \\
\text { principles of this institution and its Cooperation Program (TC41), as described earlier }\end{array}$ \\
\hline Consensus & $\begin{array}{l}\text { - Identification of the demand for training of human resources responsible for } \\
\text { health services by PAHO/Andean and Southern Cone sub-regions, in consultation } \\
\text { with national authorities }\end{array}$ \\
\hline Solidarity & $\begin{array}{l}\text { - Financing of the initiative's costs with resources from OPAS/OMS (Central Office } \\
\text { and Representation in Brazil) and the Ministry of Health of the countries involved }\end{array}$ \\
\hline Innovation & $\begin{array}{l}\text { - Proposal of the initiative to support the development of national capacities for } \\
\text { leading and directing human resources for health policies, as well as supporting } \\
\text { the formulation of action plans for the development of human resources for health } \\
\text { in the Americas region }\end{array}$ \\
\hline Sustainability & $\begin{array}{l}\text { - Adoption of strategy for training human resource managers in the countries } \\
\text { involved, offering courses for their directors, with the aim of supporting the } \\
\text { strengthening of Human Resource Observatories of the countries and promoting } \\
\text { the exchange of experiences in policies related to health education and work in the } \\
\text { region }\end{array}$ \\
\hline $\begin{array}{l}\text { - Organization of the course in two stages, }{ }^{11} \text { which enabled its content to be } \\
\text { adapted to the national needs and realities, allowing its institutionalization in local } \\
\text { universities, based on the guidelines of the Ministries of Health of the countries } \\
\text { taking part }\end{array}$ \\
\hline
\end{tabular}


Box 2 (cont.): Matrix of South-South Cooperation Directives applied to the CIRHUS case

\begin{tabular}{|c|c|}
\hline Characteristic & Development \\
\hline Sustainability & $\begin{array}{l}\text { - Participation of graduates from the course in the Andean region in the process of } \\
\text { discussing and revising the proposals for national courses }\end{array}$ \\
\hline Strategy & $\begin{array}{l}\text { - Inclusion of the initiative as part of Brazilian foreign policy, following the } \\
\text { guidelines of the National Health Program with respect to one of the geographic } \\
\text { priorities for Brazilian cooperation } \\
\text { - Justified as a project offering strategic support towards the formation of consortia } \\
\text { of international networks in investigation, human resource management and } \\
\text { education in health in the Americas region }\end{array}$ \\
\hline Transparency & $\begin{array}{l}\text { - Approval of the initiative, accompanied by inter-institutional actors in the health } \\
\text { area } \\
\text { International Advisory Service of the Ministry of Health (Aisa/MS) } \\
\text { Office of Health Work and Education Management (SGTES/MS) } \\
\text { Fundação Oswaldo Cruz Foundation (Fiocruz) } \\
\text { Pan-American Health Organization (OPAS/BRA) } \\
\text { - Progress reports available on the website of PAHO/WHO and various other } \\
\text { institutions (Observatório..., s.d.; OPAS/OMS, } 30 \text { set. 2009; Foco..., } 7 \text { set. 2009; } \\
\text { Observa..., } 3 \text { out. 2006; Ensp, } 27 \text { nov. 2008) }\end{array}$ \\
\hline Commitment & $\begin{array}{l}\text { - Support from the governments of Brazil and the other countries involved, } \\
\text { with the direct support of the Representatives of PAHO/WHO in the countries, } \\
\text { universities and teaching institutes, who ensure the replication of the course in } \\
\text { their countries }\end{array}$ \\
\hline $\begin{array}{l}\text { Leadership of the } \\
\text { South }\end{array}$ & $\begin{array}{l}\text { - Presence of countries exclusively from the "South" with emphasis on their } \\
\text { common priorities for human resources embedded within the regional } \\
\text { frameworks }\end{array}$ \\
\hline $\begin{array}{l}\text { Exchanges of } \\
\text { Experiences }\end{array}$ & $\begin{array}{l}\text { - To guarantee the competence of the International Course of Specialization in } \\
\text { Management of Human Resource for Health Policies (CIRHUS), revision of the } \\
\text { CADRHU curriculum guide, taking into account the need for adjustments in the } \\
\text { sequence of activities and updating of the texts included in the class reading lists } \\
\text { - Respect for the realities of the countries participating in the courses when } \\
\text { selecting the texts included in the Spanish-language version }\end{array}$ \\
\hline Integrality & $\begin{array}{l}\text { - Selection of participants according to their strategic positions in the national } \\
\text { institutions in which they work: directors, Ministry of Health consultants and } \\
\text { academic staff from universities in the field of human resources for health, with the } \\
\text { aim of creating teams of experts and multipliers on the theme in their countries }\end{array}$ \\
\hline Structuring & $\begin{array}{l}\text { - Contribution of the initiative to the Regional Goals of Human Resources for } \\
\text { Health 2007-2015 and the Andean Human Resources Plan (2008) by strengthening } \\
\text { administration and leadership in the management of policies and development of } \\
\text { human resources in health }\end{array}$ \\
\hline Effectiveness & $\begin{array}{l}\text { - Adaptation of the course to the realities of the four countries from the Andean } \\
\text { region (Chile, Ecuador, Peru and Colombia) among the five participants within the } \\
\text { framework of the aforementioned objectives, some of which are pursued on a } \\
\text { continuous basis } \\
\text { - Implantation of the Andean Human Resources Observatory - Rede Observa RH } \\
\text { "Edmundo Granda" na Saúde }{ }^{12} \\
\text { - Structuring of the Directorate of Strategic Development of Human Resources for } \\
\text { Health in Paraguay's Ministry of Public Health and Social Welfare }\end{array}$ \\
\hline
\end{tabular}


In this analysis, CIRHUS emerges as a successful example within the framework of Brazilian South-South Cooperation, triangulated by PAHO/WHO. Backing up this observation, it should be pointed out that the CIRHUS project was considered one of the best initiatives of this cooperation at the Global Exposition of Development on South-South Cooperation in 2009 (GSSD Expo), promoted by the Special Unit for South-South Cooperation of the United Nations Development Program.

\section{The Technical Cooperation Project "Institutional Strengthening of the Mozambican Drug Regulatory Authority as an actor in the pharmaceutical sector"}

Within the framework of the international cooperation for health provided by Brazil to Mozambique, which includes the construction of a pharmaceutical plant, the initiative analyzed here related to the Technical Cooperation Project "Institutional Strengthening of the Mozambican Drug Regulatory Authority as an actor in the pharmaceutical sector." This project was agreed in October 2008 by the Ministries of Health of Brazil and Mozambique, the ANVISA and the Brazilian Ministry of Foreign Affairs.

The project's aim is to promote capacity building and the exchange of information and experiences in the area of pharmaceutical regulation in order to institutionally strengthen the Mozambique Drug Regulatory Authority, so that the latter can act autonomously to regulate the country's pharmaceutical sector. This function of the State has become a priority, especially following the building of a local pharmaceutical production plant and the new demands for health control that emerge in this context. Guaranteeing that the medications produced in the country are high-quality, safe and effective is fundamental in terms of protecting the health of the population of Mozambique and of the countries that may eventually acquire the medications produced in this factory.

The preliminary analysis of the project's results was conducted through the travel reports of technicians from Brazil and Mozambique who participated in the execution of the project's different activities. Material for the study was also extracted from the monitoring and evaluation meetings held between the technical body of the pharmaceutical agencies and the coordination team for the international technical cooperation in both countries.

Taking as a basis the Matrix of South-South Cooperation Directives presented above, we analyze the cooperation project below in light of the fundamental aspects of South-South Cooperation, as a form of assessing this Brazilian cooperation initiative.

Box 3: Matrix of South-South Cooperation Directives applied to the Medication Project

\begin{tabular}{|c|c|}
\hline Characteristic & Development \\
\hline Horizontality & $\begin{array}{l}\text { - The project was elaborated closely in accordance with the Mozambican national } \\
\text { health priorities, which include the need for structuring its Drug Regulatory } \\
\text { Authority (DRA) } \\
\text { - The initiative of working in conjunction with Brazil's own Drug Regulatory } \\
\text { Authority came from the Mozambican Ministry of Health itself, which solicited } \\
\text { support from ANVISA towards structuring the DRA and training its technical staff, } \\
\text { as well as unilaterally recognizing the records granted and the sanitary inspections } \\
\text { conducted by the Brazilian agency }\end{array}$ \\
\hline
\end{tabular}


Box 3 (cont.): Matrix of South-South Cooperation Directives applied to the Medication Project

\begin{tabular}{|c|c|}
\hline Characteristic & Development \\
\hline Consensus & $\begin{array}{l}\text { - The bilateral cooperation project was negotiated and elaborated jointly by the } \\
\text { interested parties according to the national needs and capacities }\end{array}$ \\
\hline Equity & $\begin{array}{l}\text { - Although the financial resources for executing the activities are provided by ABC, } \\
\text { the concession of technical hours from each executing agency is planned } \\
\text { - Although ANVISA is well-advanced in terms of its institutional structure } \\
\text { for carrying out its basic regulatory functions, it is possible to learn from the } \\
\text { experience of less developed countries, know how they deal with problems and } \\
\text { the innovations that they propose, typical of countries from the South, as well } \\
\text { as the replication and divulgation of models implanted by ANVISA generates } \\
\text { international recognition and enhancement of its institutional image }\end{array}$ \\
\hline Solidarity & $\begin{array}{l}\text { - The ties of friendship, trust and culture between institutions are strengthened } \\
\text { - ANVISA has made available its most advanced work instruments and tools } \\
\text { in order to support Mozambique in the institutional strengthening of its Drug } \\
\text { Regulatory Authority }\end{array}$ \\
\hline Innovation & $\begin{array}{l}\text { - One of the characteristics of this South-South Cooperation initiative resides } \\
\text { in the fact that it receives financial and technical resources originating from } \\
\text { the 'South.' Firstly it comprises an initiative for the technology transfer of the } \\
\text { production of generic antiretroviral drugs between countries from the South- } \\
\text { South axis, as set out in WHO's Global Strategy on Public Health, Innovation and } \\
\text { Intellectual Property. Secondly it plans for the transfer of financial resources to } \\
\text { support the construction of the medications plant in Mozambique }\end{array}$ \\
\hline Sustainability & $\begin{array}{l}\text { - The national production of medications in Mozambique and technology transfer } \\
\text { for the production of pharmaceutical basically requires the existence of an } \\
\text { independent and strong Drug Regulatory Authority, possessing its own regulatory } \\
\text { framework, as one of the project's end results } \\
\text { - The stronger presence of pharmaceutical regulation in the country enables } \\
\text { more effective sanitary control of the products consumed and sold in the country, } \\
\text { independently of the political influences and economic power, given that } \\
\text { pharmaceutical regulation must be based above all on technical and scientific } \\
\text { knowledge. Hence it can be said that the project aims to strengthen national } \\
\text { institutions and autonomy in decision making }\end{array}$ \\
\hline Strategy & $\begin{array}{l}\text { - The project is based on the principles of Brazilian foreign policy and received } \\
\text { approval from the legislature for transferring resources and equipment from } \\
\text { Brazil to Mozambique, which contributed to the development of capacities in } \\
\text { Mozambique, based on the principle of structuring cooperation }\end{array}$ \\
\hline Transparency & $\begin{array}{l}\text { - The political decision to install a pharmaceutical plant in Mozambique provoked } \\
\text { a strong expectation and social repercussion } \\
\text { - The project also contributed to strengthening the regulatory framework of the } \\
\text { pharmaceutical sector in Mozambique, which guarantees greater transparency for } \\
\text { companies from the sector and for the promotion and protection of the health of } \\
\text { the country's population, as well as social participation }\end{array}$ \\
\hline Commitment & $\begin{array}{l}\text { - Political, institutional and technical commitment came from both parties, despite } \\
\text { the increased demands on the Brazilian DRA and the fact that some sanitary } \\
\text { regulations approved by the Mozambican government are subject to political } \\
\text { influences }\end{array}$ \\
\hline Leadership of the "South" & $\begin{array}{l}\text { - The project contributes to strengthening the DRA of Mozambique, which has the } \\
\text { role of autonomously and independently regulating the national pharmaceutical } \\
\text { sector in accordance with the health situation in the country and the WHO } \\
\text { guidelines }\end{array}$ \\
\hline
\end{tabular}


Box 3 (cont.): Matrix of South-South Cooperation Directives applied to the Medication Project

\begin{tabular}{|l|l|}
\hline Characteristic & Development \\
\hline Leadership of the "South" & $\begin{array}{l}\text { - Likewise, foreign aid for health, which the African country depends on, can be } \\
\text { better coordinated and defined, in accordance with national priorities, if these } \\
\text { WHO recommendations are followed }\end{array}$ \\
\hline Exchange of experiences & $\begin{array}{l}\text { - There is a significant exchange of information and experiences between } \\
\text { agencies, which generates mutual learning }\end{array}$ \\
\hline Integrality & $\begin{array}{l}\text { - Brazilian technical cooperation in Mozambique receives the support and } \\
\text { effective participation of diverse institutions from the health sector. In addition, } \\
\text { there is an attempt to coordinate this cooperation as part of achieving a } \\
\text { "structuring" type of cooperation strategy }\end{array}$ \\
\hline Structuring & $\begin{array}{l}\text { - There is a concern with the development of capacities at all levels: technical, } \\
\text { organizational and institutional } \\
\text { - Brazilian professional can be found working in various intervention areas in } \\
\text { Mozambique. The difference between the Brazilian professionals and those from } \\
\text { other nations is that the former is the awareness of being in the country for a } \\
\text { set time and the commitment to the project's continuity. Hence the concern of } \\
\text { Brazilian cooperation is to generate local knowledge and reduce the dependency } \\
\text { of the cooperating countries }\end{array}$ \\
\hline $\begin{array}{l}\text { - Coordination is attempted with different foreign aid institutions but each } \\
\text { institution present in the country has its own defined program and, to a certain } \\
\text { extent, aims to operate independently in terms of foreign aid. The existence } \\
\text { of innumerable agencies and actors with their own interests hinders the } \\
\text { coordination and harmonization of cooperation. Better communication needs to } \\
\text { be fostered between international donors so that a joint coordinated program can } \\
\text { be elaborated }\end{array}$ \\
\hline
\end{tabular}

\section{Final considerations}

The closer relations between countries of the "South" today allows the exchange of technical and scientific knowledge, based on the principles of solidarity and horizontality, among other characteristics. Even so the material interests and power asymmetries are still not entirely excluded from South-South relations. Some "Southern" countries demand economic returns for the cooperation provided to other countries with a relatively lower level of development. Emerging countries can take advantage of the lack of infrastructure and workforces in sub-Saharan African or Southeast Asian countries, for example, and bind technical cooperation to the purchase of materials and equipment from their own country. They may even use their own human resources to execute activities so that not even the available local capacity, albeit limited, is utilized.

In this respect, basic principles of South-South Cooperation need to be observed, including equity and consensus, so that the differences and asymmetries do not represent the imposition of models and priorities of some countries on others.

As discussed above, the priorities and characteristics of Brazil's cooperation - related to the adoption of concepts like "South-South Cooperation" and "structuring cooperation for health" - form part of the government's official political agenda. Brazil undoubtedly has diverse interests (commercial, political, economic, cultural) beyond a proposal of solidarity 
with the countries with which it cooperates. However the interests that can exist behind the explicit objectives are not perhaps so evident.

On the other hand, we can observe that, through the practical cooperation experiences analyzed here, the technical work presently being carried out is achieving positive results in terms of the objectives and characteristics of South-South Cooperation. The execution of the technical activities of the cooperation projects maintains a concern with the development of local capacities in the countries with which Brazil cooperates, seeks to meet the national priorities and needs, respects the sovereignty and autonomy of the countries in the steering of State policies, and takes into account the limitations that may exist in each of them.

The effectiveness of these actions, nonetheless, depends to a large extent on the commitment and capacities available in the country in order to implant and absorb the knowledge exchanged through Brazilian cooperation.

The study led to the elaboration of a proposal for a "Matrix of South-South Cooperation Directives," subsequently used to analyze two cases of Brazilian international cooperation. As a challenge, the investigation could be continued through the development of indicators measuring the extent to which the initiatives studied matches the characteristics.

The need for the proposal to be discussed and fine-tuned with the combined effort of the academic, scientific and technical community is fully recognized, anticipating its use as a means of ensuring better planning and monitoring of international technical cooperation activities undertaken in a spirit of solidarity.

\section{NOTES}

${ }^{1}$ A group of non-aligned countries in the United Nations, led by Brazil, India and Mexico. Formed in 1964 and founded at the United Nations Conference on Trade and Development (UNCTAD), is a coalition of developing nations that seeks to promote the collective economic interests of its members and create greater joint negotiation capacity.

${ }^{2}$ Southern Common Marker: a sub-regional economic whose member countries comprise Argentina, Brazil, Paraguay, Uruguay and Venezuela, with the participation of Chile, Peru, Colombia, Ecuador and Bolivia as Associate States.

${ }^{3}$ USAN was conceived in 2004 during the Cuzco Summit and officially founded during the First Summit of Heads of State of the Union of South American Nations in Brasilia in September 2005 with the approval of the entity's governing body. According to Article 2 of its Constitutive Treaty, USAN (cf. Unasur, s.d.) has the objective of "build a space of integration and cultural, social, economic and political union between its peoples, granting priority to political dialogue, social policies, education, energy, infrastructure, financing and the environment, among other areas, with the aim of eliminating socioeconomic inequality, achieving social inclusion and citizen participation, strengthening democracy and reducing the asymmetries within the framework of strengthening the sovereignty and independence of the States."

${ }^{4}$ Angola, Cape Verde, Mozambique, São Tomé and Príncipe, Brazil, Guinea-Bissau, Portugal and East Timor.

${ }^{5}$ Approved at the Second Meeting of the CPLP Ministers of Health held in the city of Estoril, Portugal, on 15 May 2009, and renewed in 2012, in Lisbon.

${ }^{6}$ SEGIB is an international body created during the $13^{\text {th }}$ Ibero-American Conference to serve as a permanent organ providing institutional and technical support to the Conference (http://segib.org/pt).

${ }^{7}$ Elaborated by the High-Level Committee on the United Nations for Review of TCDC in 1995.

${ }^{8}$ Approved in 2005 during the High-Level Conference on South-South Cooperation, also known as the 'Second Encounter of the South,' the plan should provide a definitive impulse to South-South Cooperation in all of the world's regions and in all its modalities (G-77, jun. 2005).

${ }^{9}$ In 2003, the United Nations General Assembly formally opted to use the expression "South-South" instead of "TCDC" when referring to cooperation between developing countries. 
${ }^{10}$ In September 2007, the $27^{\text {th }}$ Pan-American Sanitary Conference ratified Resolution CSP27.R7, Regional Goals for Human Resources for Health 2007-2015. A series of 20 Regional Goals for Human Resources for Health (2007) was organized on the five critical challenges identified in the Toronto Call to Action 20062015: Towards a decade of Human Resources in Health for the Americas.

\section{REFERENCES}

ALMEIDA Célia et al.

A concepção brasileira de cooperação Sul-Sul estruturante em saúde. RECIIS, v.4, n.1, p.2535. Disponível em: http://www6.ensp.fiocruz. br/radis/sites/default/files/pdf/a-concepcaobrasileira-de-cooperacao-sul-sul-estruturanteem-saude.pdf. Acesso em: 22 dez. 2013. mar. 2010.

AMADOR, Ethel A.

El nuevo rostro de la CTPD y las nuevas tendencias internacionales. Revista de Ciencias Sociales, v.4, n.94, p.169-188. 2001.

AMORIM, Celso.

Os Brics e a reorganização do mundo. Folha de S.Paulo. Tendências e Debates, Opinião, A3, p.8. 8 jun. 2008.

BRASIL.

Ministério da Saúde. Secretaria-Executiva. Plano Nacional de Saúde: 2012-2015. Série B. Textos Básicos de Saúde. Brasília: Editora do Ministério da Saúde. 2011.

BRASIL.

Ministério da Saúde. Assessoria Internacional. Ciclo de Debates: participação do Ministério da Saúde no Cenário Internacional da Saúde. Disponível em: http://189.28.128.100/portal/ arquivos/pdf/ms_cenario_internacional_saude. pdf. Acesso em: 7 nov. 2009. 2009.

BRASIL.

Ministério da Saúde. Secretaria-Executiva. Mais saúde: direito de todos: 2008-2011/Ministério da Saúde, Secretaria-Executiva. Brasília: Editora do Ministério da Saúde. 2008.

BRASIL.

Constituição da República Federativa do Brasil de 1988. Disponível em: http://www.planalto. gov.br/ccivil_03/Constituicao/Constituicao.htm. Acesso em: 20 dez. 2013. 1988.

\section{BRASIL.}

Agência Brasileira de Cooperação. Conceito. Brasília: Ministério das Relações Exteriores. Disponível em: http://www.abc.org.br/CooperacaoTecnica/ Conceito. Acesso em: 9 nov. 2012. s.d.a.

BRASIL.

Agência Brasileira de Cooperação. Histórico da Cooperação Técnica Brasileira. Brasília: Ministério das Relações Exteriores. Disponível em: http://
www.abc.org.br/CooperacaoTecnica/Historico. Acesso em: 9 nov. 2009. s.d.b.

BRASIL.

Agência Brasileira de Cooperação. Vertentes da Cooperação Técnica Internacional. Brasília: Ministério das Relações Exteriores. Disponível em: http://www.abc.org.br/CooperacaoTecnica/ Vertentes. Acesso em: 30 nov. 2012. s.d.c.

CASON, Jeffrey.; POWER, Timothy. Presidentialization, pluralization, and the rollback of Itamaraty: explaining change in the Brazilian foreign policy making from Cardoso to Lula. International Political Science Review/Revue internationale de science politique, v.30, n.2, p.117140. 2009.

DALLARI, Dalmo de Abreu.

Ética sanitária. In: Aranha, Márcio Iorio

(Org.). Direito sanitário e saúde pública. Brasília: Ministério da Saúde. p.65-86. 2003.

DINIZ, Eugênio.

Realismo, institucionalismo liberal e a inserção internacional do Brasil: uma agenda de pesquisa empírica. In: Esteves, Paulo Luiz. Instituições Internacionais: segurança, comércio e integração. Belo Horizonte: PUC Minas. 2003.

ENSP.

Escola Nacional de Saúde Pública Sergio Arouca. Formação de RH é central para sistema de saúde mais solidário. Informe Ensp. Rio de Janeiro: Ensp. Disponível em: http://www.ensp.fiocruz.br/portalensp/informe/site/materia/detalhe/14211. Acesso em: 19 out. 2009. 27 nov. 2008.

\section{FIOCRUZ.}

A Cooperação Internacional Desenvolvida pela Escola Nacional de Saúde Pública Sérgio Arouca da Fundação Oswaldo Cruz com a África. Boletim Técnico Institucional 2008. Disponível em: http://www5.ensp.fiocruz.br/biblioteca/dados/ txt_235056090.pdf. Acesso em: 8 nov. 2009. 2008.

FOCO...

Foco na Cooperação Sul-Sul. São Paulo: Bireme/ Opas/OMS. Disponível em: http://cspace. eportuguese.org/tiki-read_article.php?articleId=79. Acesso em: 19 out. 2009. 7 set. 2009.

G-77.

The Group of 77at the United Nations. Plan de Acción de Doha. Doha: G-77. Disponível 
em: http://www.g77.org/southsummit2/doc/ Doha\%20Plan\%20of\%20Action\%20(Spanish). pdf. Acesso em: 21 dez. 2013. jun 2005.

KEOHANE, Robert.

Lilliputian's dilemmas: small States in international politics. International Organization, v.23, n.2. 1969 .

LIMA, Maria Regina Soares de.

Brazil rising: the country's new status means reconciling divergent interests with the North, the South, and its neighbors. IP Journal.

Disponível em: https://ip-journal.dgap.org/en/ipjournal/regions/brazil-rising. Acesso em: 19 out. 2009. 1 jan. 2008.

LIMA, Maria Regina Soares de.

A política externa brasileira e os desafios da cooperação sul-sul. Revista Brasileira de Política Internacional, v.48, n.1, p.24-59. 2005.

LULA DA SILVA, Luiz Inácio.

Discurso de posse do presidente Luiz Inácio Lula da Silva. (Em 1 de jan. 2007). Disponível em: http://www.fiec.org.br/artigos/temas/discurso_ de_posse_do_presidente_Luiz_Inacio_Lula_da Silva.htm. Acesso em: 9 nov. 2009. 1 jan. 2007.

LULA DA SILVA, Luiz Inácio.

Discurso de posse do presidente Luiz Inácio Lula da Silva no Congresso. (Em 1 de jan. 2003). Folha de S.Paulo. Poder. Disponível em: http://www1. folha.uol.com.br/folha/brasil/ult96u44275.shtml. Acesso em: 9 nov. 2009. 1 jan. 2003.

MALISKA, Marcos Augusto.

Cooperação internacional para os direitos humanos entre o direito constitucional e o direito internacional. Revista Forense, v.391. maio-jun. 2007.

MALISKA, Marcos Augusto.

Estado constitucional cooperativo, democracia e parlamento em instituições supranacionais e intergovernamentais (Entrevista com Peter Häberle). Cadernos da Escola de Direito e Relações Internacionais da Unibrasil, n.6, p.75-81. jan.-dez. 2007.

NASLAUSKY, Marco Meira.

Los nuevos paradigmas de la Cooperación Internacional. Revista Capítulos, n.64. jan.-abr. 2002.

OBSERVA...

Observa RH Nesp/Cean/UnB. CIRHUS e os desafios dos recursos humanos. Brasília: Nesp/Cean/UnB. Disponível em: http:// www.observarh.org.br/nesp/busca. php? busca $=$ Cirhus\&x=0\&y=0. Acesso em: 17 out. 2009. 3 out. 2006.

OBSERVATÓRIO...

Observatório Andino de Recursos Humanos Red
ObservaRH "Edmundo Granda".

Disponível em: http://www.observarh.org/. Acesso em: 19 de outubro de 2009. s.d.

OECD.

Organisation for Economic Co-operation and Development. Declaración de París sobre la Eficacia de la Ayuda al Desarrollo: apropiación, armonización, alineación \& resultados y mutua responsabilidad. Paris: OECD. Disponível em: http://www.oecd.org/dac/ effectiveness/34580968.pdf. Acesso em: 15 out. 2009. 28 fev.-2 mar. 2005.

\section{OPAS/OMS.}

Organização Pan-americana da Saúde/Organização Mundial da Saúde. Região Andina inicia CIRHUS pelo Equador. Programa de Cooperação Internacional em Saúde. Brasília: Opas/OMS. Disponível em: http://new.paho.org/bra/index. php?option=com_content\&task=view\&id=693\&It emid=643. Acesso em: 19 out. 2009. 30 set. 2009.

\section{OPAS/OMS.}

Organização Pan-americana da Saúde/Organização Mundial da Saúde. Estratégia de Cooperação Técnica da OPAS/OMS com a República Federativa do Brasil, 2008-2012. Brasília: Opas. 2007.

OPAS/OMS.

Organização Pan-americana da Saúde/ Organização Mundial da Saúde. Cooperação Internacional em Saúde no Congresso Abrasco. Programa de Cooperação Internacional em Saúde. Brasília: Opas/OMS. Disponível em: http://www.paho.org/bra/index. php?option=com_content $\&$ view $=$ article $\& i d=305$ $8 \&$ Itemid=643. Acesso em: 22 nov. 2010. s.d.

QUEIROZ, Luciano Ávila.

A crescente demanda da cooperação sulsul na área da saúde e a estrutura do Ministério da Saúde. Brasília: Opas/OMS. Disponível em: http://www.paho.org/bra/ index.php?option=com_docman\&task $=$ doc view\&gid=841\&Itemid=614. Acesso em: 31 out. 2014. 2008.

SARAIVA, José Flávio Sombra.

CPLP: Plataforma para uma frutífera concertação político-diplomática. In: Saraiva, José Flávio Sombra (Org.). Comunidade dos países de língua portuguesa (CPLP): solidariedade e ação política. Brasília: Ibri. 2001.

SEGIB.

Secretaria General Iberoamericana. II Informe de la Cooperación Sur-Sur en Iberoamérica. Madrid: Segib. 2008.

TEMPORÃO, José Gomes.

Discurso de posse do dr. José Gomes Temporão no cargo de Ministro da Saúde em 19 mar. 2007. 
Disponível em: http://www5.ensp.fiocruz.br/ biblioteca/dados/arq5068.pdf. Acesso em: 8 nov. 2009. 2007.

UNASUR.

Unión de Naciones Suramericanas. Tratado Constitutivo de la Unión de Naciones Suramericanas. Quito: Unasur. Disponível em: http://www.comunidadandina.org/unasur/ tratado_constitutivo.htm. Acesso em: 30 set. 2009. s.d.

\section{UNDP.}

United Nations Development Programme. Forging a Global South South: United Nations Day for South-South Cooperation. New York: UNDP. Disponível em: http://www.ctc-health.org.cn/ file/2012060807.pdf. Acesso em: 20 dez. 2013. 19 dez. 2004.

\section{UNDP.}

United Nations Development Programme.

Capacity development: technical advisory paper n.2. Management Development and Governance
Division, Bureau for Policy Management. New York: UNDP. Disponível em: http://mirror.undp. org/magnet/Docs/cap/Capdeven.pdf. Acesso em: 15 mar. 2009. 1997.

UNITED NATIONS.

United Nations Day for South-South

Cooperation. Disponível em: http://www.un.org/ en/events/southcooperationday/background. shtml. Acesso em: 23 dez. 2013. 12 set. 2012.

\section{UNITED NATIONS.}

General Assembly. Resolution A/62/295. The state of South-South cooperation. Disponível em: http://www.un.org/en/ga/search/view_doc. asp?symbol=A/62/295. Acesso em: 23 dez. 2013. 2007.

VICTORIA, Diego.

Apresentação. In: Organização Pan-americana da Saúde (Opas). Cooperação técnica entre países para a formação de dirigentes de recursos humanos em saúde. Brasília: Opas. 2010. 